\title{
Unventilated Cigarette
}

National Cancer Institute

\section{Source}

National Cancer Institute. Unventilated Cigarette. NCI Thesaurus. Code C162672.

A cigarette that incorporates a conventional filter. 